\title{
FLUORIDE CONCENTRATION IN WATER AT THE AREA SUPPLIED BY THE WATER TREATMENT STATION OF BAURU, SP
}

\author{
CONCENTRAÇÃO DE FLUORETO NA ÁGUA DO SETOR ABASTECIDO PELA ESTAÇÃO \\ DE TRATAMENTO DE ÁGUA DE BAURU, SP
}

Carolina Simonetti LODI ${ }^{1}$, Irene RAMIRES ${ }^{2}$, Marília Afonso Rabelo BUZALAF ${ }^{3}$, José Roberto de Magalhães BASTOS ${ }^{4}$

1- Graduate Student in Pediatric Dentistry at the Hospital for Rehabilitation of Craniofacial Anomalies, USP.

2- MSc in Community Dentistry by University of São Paulo, Bauru Dental School, FOB/USP.

3- Associate Professor of the Department of Biological Sciences, Discipline of Biochemistry at Bauru Dental School, FOB/USP.

4- Chairman Professor of Preventive Dentistry, Department of Pediatric Dentistry, Orthodontics and Community Dentistry, Discipline of Community Dentistry at Bauru Dental School, FOB/USP.

Corresponding address: Profa. Dra. Marília Afonso Rabelo Buzalaf - Universidade de São Paulo - Faculdade de Odontologia de Bauru Al. Dr. Octávio Pinheiro Brisolla, 9-75 - Cep.: 17 012-301 - Bauru - SP - Tel: (14) 32358346 - e-mail: mbuzalaf@fob.usp.br

Received: January 04, 2006 - Modification: June 19, 2006 - Accepted: August 29, 2006

\begin{abstract}
O

bjective: to analyze the fluoride concentration in the public water supply at the area supplied by the Water Treatment Station of Bauru and classify the samples as acceptable or unacceptable according to the fluoride concentration. Material and methods: samples were collected from 30 areas at two periods, October 2002 and March 2003. The fluoride concentration in the samples was determined in duplicate, using an ion sensitive electrode (Orion 9609) connected to a potentiometer (Procyon, model 720). Samples with fluoride concentration ranging from 0.55 to $0.84 \mathrm{mg} \mathrm{F} / \mathrm{L}$ were considered acceptable, and those whose concentration was outside this range as unacceptable. Data were analyzed by descriptive statistics. Results: the fluoride concentration of the water samples varied between 0.31 and $2.01 \mathrm{mg} \mathrm{F} / \mathrm{L}$. Nearly $56 \%$ of the samples were classified as acceptable. Conclusion: the variations in fluoride concentration at the area supplied by the Water Treatment Station reinforce the need of constant monitoring for maintenance of adequate fluoride levels in the public water supply.

Uniterms: Fluoride; Water fluoridation; Monitoring.
\end{abstract}

\section{RESUMO}

$\mathrm{O}$

bjetivo: Analisar a concentração de fluoreto da água de abastecimento público do setor abastecido pela Estação de Tratamento de Água de Bauru e classificar as amostras em aceitáveis ou inaceitáveis de acordo com a concentração de flúor. Material e Métodos: Foram coletadas 238 amostras de 30 bairros em duas etapas, Outubro de 2002 e Março de 2003. A concentração de fluoreto presente nas amostras foi determinada em duplicata, utilizando-se o eletrodo íon sensível (Orion 9609), acoplado ao potenciômetro (Procyon, modelo 720). As amostras com concentração de flúor variando entre 0,55 e 0,84 mg F/L foram consideradas como aceitáveis e aquelas cuja concentração estava fora do intervalo, como inaceitáveis. Os dados foram analisados por meio de estatística descritiva. Resultados: A concentração de fluoreto das amostras de água variou entre 0,31 e 2,01 mg F/L, sendo que cerca de $56 \%$ das amostras foram classificadas como aceitáveis. Conclusão: A variação na concentração de fluoreto do setor abastecido pela ETA reforça a importância de um monitoramento constante da fluoretação para a manutenção dos níveis adequados de fluoreto na água de abastecimento.

Unitermos: Flúor; Fluoretação da água; Monitoramento. 


\section{INTRODUCTION}

Fluoridation of the public water supply was initially adopted as a measure to control dental caries after several studies conducted in the 1940s and 1950s, in the USA ${ }^{1,7}$. The World Health Organization, in 1958, acknowledged the importance of fluoridation and indicated it as a public health measure $^{28}$.

In Brazil, the Federal Law n. 6050 was established on May $24^{\text {th }} 1974$, which addresses the water fluoridation in public supply systems, regulated by the Federal Decree $n$. 76872 of December $22^{\text {nd }} 1975$, that establishes the obligatoriness of fluoridation and determines that "projects directed towards construction or widening of public water supply systems, where there is a treatment station should include provisions and plans on water fluoridation"5,6.

Fluoridation of the public water supply in Bauru was established on October $10^{\text {th }} 1975$, at the Water Treatment Station (ETA). In 1985, nearly $71 \%$ of the population (130 thousand inhabitants) received fluoridated water, and the ETA supplied nearly $60.4 \%$ of the population, which corresponded by that time to $84.5 \%$ of the population receiving fluoridated water ${ }^{13}$. After 1990, the Water and Sewerage Department (DAE) of Bauru reached $100 \%$ of water chlorination and fluoridation. In 2003, the population of the city was approximately 326,392 inhabitants, from which $44 \%$ was supplied by ETA ${ }^{12}$. Water fluoridation has been based on the mean maximum daily temperature, and thus the ideal concentration is $0.7 \mathrm{mg} \mathrm{F} / \mathrm{L}^{9}$.

The therapeutic effects of fluoride, widely acknowledged in public health actions, are larger when the water is used as a vehicle due to its collective nature, effectiveness, cost and frequency of consumption ${ }^{7,9,16,18,28,29}$. Also, the Center for Disease Control and Prevention (CDC) at the USA classified fluoridation of the public water supply as one of the ten most important public health achievements in the $20^{\text {th }}$ century ${ }^{10}$.

However, it should be highlighted that effective control of dental caries requires the adequacy and continuous maintenance of fluoride content, by regular fluoridation procedures $^{7,9,16,18,24,28,29}$. Some studies were conducted in Bauru $^{9,26,27}$ and other Brazilian cities , 15,20,25,30 $^{\text {, besides several }}$ other countries ${ }^{4,8,11,14,17,19}$, in order to verify the fluoride concentration in the public water supply. All studies mentioned revealed important variations in fluoride concentration in the public water supply.

Considering that constant monitoring of fluoridation equipments as well as maintenance of fluoride concentration within the recommended values is necessary and difficult to be achieved in many cities, as well as in Bauru ${ }^{9,26,27}$, the external control of water fluoridation is an important measure. Thus, the present study evaluated the fluoridation of water supplied by the largest distribution area (ETA) in this city. For such purpose, water samples were collected throughout this sector, on two different periods.

\section{MATERIALAND METHODS}

The water supply system of the city comprises 19 sectors, and the water supply is maintained by ETA, with utilization of superficial waters of the Batalha River and 27 wells for catching of underground waters (Guarani Aquifer). The fluoride compound used for fluoridation is the hydrofluosilicic acid and the system consists in a small metering pump to add solutions of the acid directly into the water supply. Since 1999 the system measures immediate water flow and adjusts amounts of fluoride ${ }^{9}$. The supply of this system is formed by a network of tubes with nearly 1,500 kilometers of extension. Each sector is supplied by one or more wells, besides the sector supplied by ETA, through its several reservoirs. This is the largest and most populous supply sector of the city, with nearly 150 thousand inhabitants ${ }^{26}$.

\section{Areas of collection and water samples}

The areas of collection were established according to the map provided by the Water and Sewerage Department of Bauru (DAE), in which 30 areas were selected from the 46 areas supplied by ETA. Four homes were visited in each area at two periods. The first period of collection was performed in October 2002 and the second in March 2003. For both periods the samples were collected in one day. The exclusion of some areas was related to the difficult access and in some cases due to the lack of security for the investigators. Thus, a total of 240 water samples were achieved, with collection of 120 water samples in each day. Before performing collection of water samples in the homes, the inhabitants received the Informed Consent Term with information on the study and its importance. After agreeing to participate, the inhabitant signed the Consent Term. The investigation was evaluated and approved by the Institutional Review Board of Bauru Dental School, FOB/ USP.

\section{Collection of water samples}

The water was collected in $100 \mathrm{~mL}$ plastic flasks, specifically purchased for the study and without previous contact with any type of substance. Before collection, the flasks were labeled for later identification (area, street, number of the home) and washed with tap water at the area of collection, following the technique recommended for this procedure. The samples were collected at the point of entry of water, to reproduce the conditions in which it is distributed and arrives to the homes. The samples were stored in a chamber at $-20^{\circ} \mathrm{C}$ up to analysis.

\section{Fluoride analysis}

The fluoride concentration present in the water samples was determined in duplicate, using the ion sensitive electrode (Orion 9609), connected to a potentiometer (Procyon, model 720), using $1.0 \mathrm{~mL}$ of the sample to which $1.0 \mathrm{~mL}$ of TISAB II (Orion) was added. The electrode was previously calibrated with standard solutions containing $0.1,0.2,0.4,0.8,1.6$ or $3.2 \mathrm{mg} \mathrm{F} / \mathrm{L}$. The results of analyses of 
the water samples were checked by second reading of $10 \%$ of the samples.

\section{Classification of samples}

The fluoride concentration found in the samples was used to classify them according to the criteria established by Narvai $^{24}$, as modified by Ramires ${ }^{26}$. According to this classification system, the samples are considered "acceptable" when they present a fluoride concentration between 0.55 and 0.84 ppm (mg F/L). This category comprises the "under fluoridated", "optimal” and "over fluoridated" situations. When the fluoride concentration is comprised between 0.85 and $1.14 \mathrm{ppm}$, samples are classified as "inadequate", and above this concentration, as “unacceptable” (Table 2).

\section{Data analysis}

Data were analyzed by descriptive statistics.

\section{RESULTS}

In October 2002 and March 2003, a total of 238 water samples were collected from the 240 samples initially determined. There was loss of 2 areas of collection, since there was no inhabitant at home at the moment of collection.

The mean fluoride concentration observed in each area of collection in the two months varied from $0.31 \mathrm{mg} \mathrm{F} / \mathrm{L}$ (Area $\mathrm{X}$ ) to $2.01 \mathrm{mg} \mathrm{F} / \mathrm{L}$ (Area XVII), and the mean observed for the entire period (October 2002 and March 2003) varied between $0.48 \mathrm{mg} \mathrm{F} / \mathrm{L}$ (Area XXVI) and $1.12 \mathrm{mg} \mathrm{F} / \mathrm{L}$ (Area XVII). The mean fluoride concentration observed in the sector supplied by ETA in each step of the study, in October and March, was 0.56 and $0.65 \mathrm{mg}$ F/L, respectively. For the entire period, considering the two months of collection, the mean was $0.61 \mathrm{mg} \mathrm{F/L}$ (Table 1).

According to the fluoride concentration in the water samples, nearly $40 \%$ were classified as unacceptable (for caries control), $27 \%$ as under fluoridated, $21 \%$ as optimal, $8 \%$ as over fluoridated, $1 \%$ as inadequate and $3 \%$ as unacceptable (risk of fluorosis). Thus, $56 \%$ of the samples presented acceptable fluoride concentration, between 0.55 and $0.84 \mathrm{mg} \mathrm{F} / \mathrm{L}$ (Table 2).

\section{DISCUSSION}

The results indicated a large variation in the fluoride concentration in water at the sector supplied by ETA. This variation was observed in October, between 0.31 and 2.01 mg F/L, and also in March, despite smaller, between 0.37 and $0.85 \mathrm{mg} \mathrm{F} / \mathrm{L}$. Analysis of the data in Table 1 reveal that in October there was a clear tendency toward low fluoride concentrations in water, when 85 samples presented fluoride concentration between 0.31 and $0.54 \mathrm{mg} / \mathrm{L}$, even though the highest concentration observed in the study, $2.01 \mathrm{mg} \mathrm{F} / \mathrm{L}$, was also from this period. The mean fluoride concentration of the sector, analyzed separately from the results of each area, at both periods of collection ( 0.56 and $0.65 \mathrm{mg} \mathrm{F} / \mathrm{L}$ for October and March, respectively), suggests a good fluoridation system. However, upon separate analysis of each point of collection, the set of data reveals failures in the fluoridation system, and the values observed are very close to those found by Ramires ${ }^{26}$ in 2004.

The mean fluoride concentration observed in the samples of each area ranged from 0.48 to $1.12 \mathrm{mg} \mathrm{F} / \mathrm{L}$ (Table 1 ). The variation between the means is important, since it indicates instability in the water fluoridation at the sector. For the Area XVII, specifically, the mean of $1.12 \mathrm{mg}$ F/L was established due to the high concentration observed in October (between 1.50 and $2.01 \mathrm{mg}$ F/L), which were not repeated in March, when they were lower (between 0.37 and $0.55 \mathrm{mg}$ F/L). This area presented the largest variation between months. However, other areas also presented important variations, such as III, IV, V, X, XI and XII (Table 1).

An important aspect is that in some areas the samples presented predominance of low fluoride concentrations, as in areas XIX, XXI, XXIII, XXV, XXVI and XXVII. In these areas, the mean of October and March was lower than 0.55 mg F/L. On the other hand, in areas VIII and IX the water constantly presented a fluoride concentration close to the ideal, with means for the periods of $0.75 \mathrm{mg} \mathrm{F} / \mathrm{L}$ and $0.73 \mathrm{mg}$ F/L, respectively (Table 1 ).

Concerning the classification of water samples according to the fluoride concentration, in October nearly $74 \%$ of the samples were classified as unacceptable, different from March, with $43 \%$ of samples in this category (Table 2). Another important data is that the percentage of optimal samples, 6.7\% in October and 36\% in March, remarkably influenced the total number of acceptable samples (24\% in October and 89\% in March).

Among the cited factors that have been suggested to explain variations in water fluoride concentrations are size of the population, problems with the fluoride compound used, type and number of water sources, size of the water plant, variations in the main water flow, seasonal variations, water plant operator (training, age, turnover, full-time or not), equipment problems and type of test to monitor results ${ }^{9}$. The ETA supplies around 150,000 inhabitants. In Bauru it is used hydrofluosilicic acid, which is considered easier to use, because it mixes more rapidly and uniformly to the water than powder compounds. However, its production is seasonal, which implies that cities have to stock it for some periods. This could explain some interruptions in water fluoridation in some cities. The region supplied by the ETA uses surface water from the Batalha river and this source has been shown to have only trace raw fluoride levels, with no considerable seasonal variations ${ }^{26}$. Thus, this factor may not be responsible for the variations in water fluoride levels detected.

In respect to the water plant operators in Bauru, they are full-time, but they do not attend to periodic training programs. Most of them are not graduated from college and we could observe a lack of information concerning the risks of hyper and hypofluoridation. This may have had some 
influence on the results observed in the present study. Thus, a periodic training of these operators should be conducted, in order to improve the fluoridation system.

Additionally, it should be highlighted that the samples in October and March were collected in a single day. This fact gives rise to another hypothesis to explain the variation in fluoride concentration observed at the same day at the different areas of the sector and even in a same area. The
ETA has several water reservoirs at several parts of the sector to enhance the distribution, maintenance of supply and also the repair of equipments. These resources are important to avoid collapse of the sector in case of need of repair of part of the network. Also, it should be considered that each reservoir has different abilities of storage and consumption. Thus, the water arriving to a home in the area was not necessarily fluoridated at the same moment and

TABLE 1- Fluoride concentration in the water samples collected in October 2002 and March 2003, at 4 points of 30 areas supplied by ETA (Sector I) in Bauru, SP, Brazil

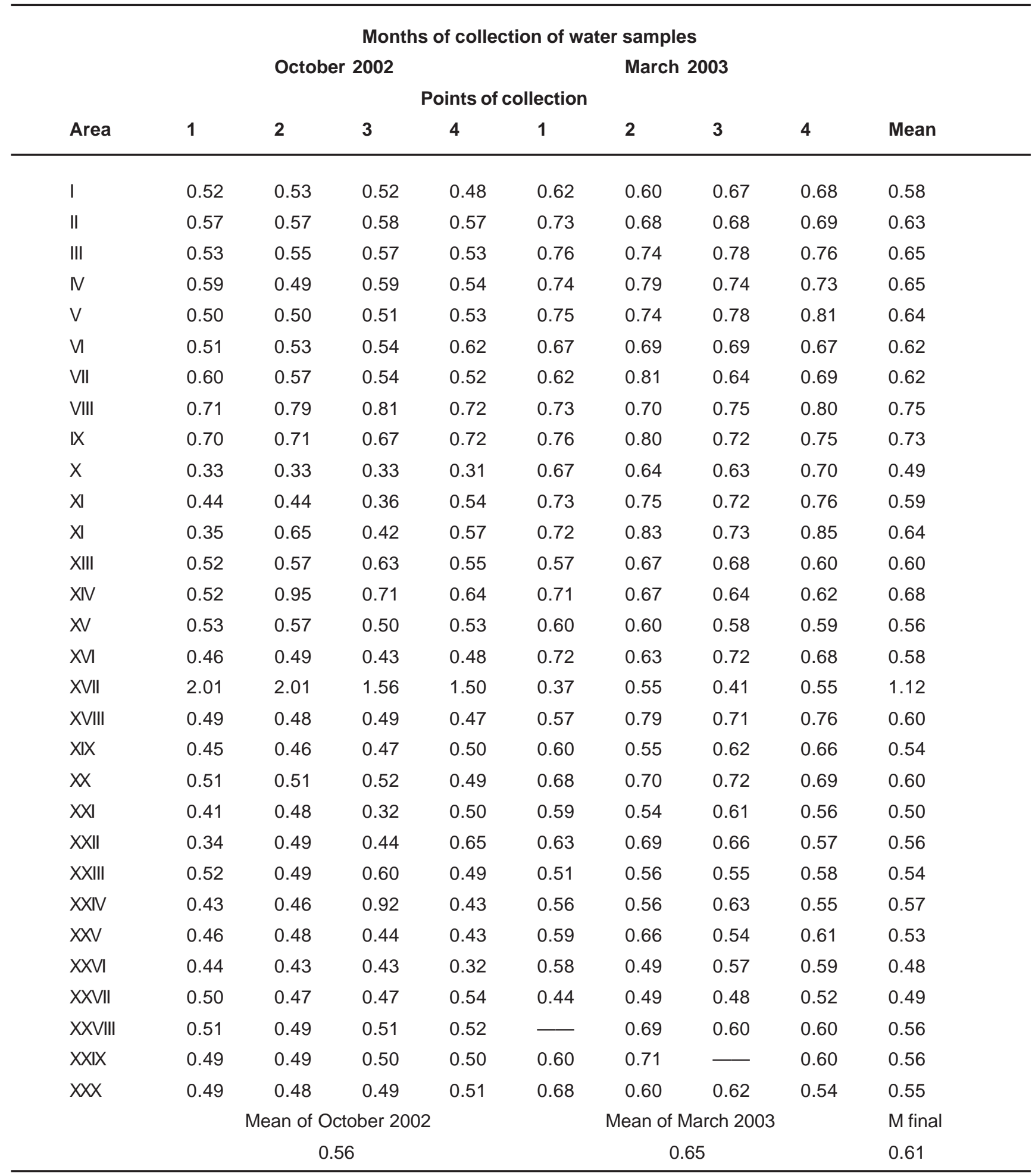


maybe not even in the same day compared to another area of the sector. Also, during the day there may be variations in the fluoride dosage during the fluoridation process. It should be mentioned that this supply sector, due to its extension, is bordered by several other sectors, which may allow mixture of water in some places.

Even though these hypotheses may help to explain the variations observed in fluoride concentration, they do not completely explain the occurrence of so many fluctuations in only two days of collection. Moreover, the laboratory of DAE, which controls the fluoridation of the entire supply system of Bauru, is located at the facilities of ETA, which should enhance the control of the fluoridation process performed at the station. Furthermore, the analysis of fluoride performed by ETA involves the same methodology used in the present study.

The results of other studies conducted in Bauru were not different $t^{9,26,27}$. The difficulty of public water supply systems to keep a constant fluoride concentration is not a peculiarity of the city. Several studies conducted in other Brazilian cities reveal the same difficulty $\mathrm{y}^{2,15,20,25,30}$, as well as

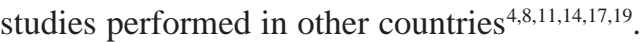

\section{CONCLUSION}

The variations in fluoride concentration at the area supplied by the Water Treatment Station reinforce the need of a constant external control for the maintenance of adequate fluoride levels in the public water supply.

\section{REFERENCES}

1- Axelsson P. Use of fluorides. In: Axelsson P. Preventive materials, methods, and progams. Chicago: Quintessence Books; 2004. p.263368.

2- Barros ERC, Tovo MF, Scapini C. Análise crítica da fluoretação das águas. Rev Gauch Odontol. 1990;38(4):247-54.
3- Barros ERC, Scapini C, Tovo MF. Resultados da fluoretação da água. Rev Gauch Odontol. 1993;41(5):303-8.

4- Booth IM, Mitropoulos CM, Worthington HV. A comparison between the dental health of 3-year-old children living influoridated Huddersfiel and non fluoridated Dewsburg in 1989. Community Dent Health. 1991;9:151-7.

5- Brasil. Ministério da Saúde. Lei Federal nº 6050, de 24 de maio de 1974. Diário Oficial da República Federativa do Brasil, Brasília; 1974.

6- Brasil. Ministério da Saúde. Decreto $n^{0}$ 76.872, de 22 de dezembro de 1975: regulamenta a lei $n^{\circ} 6050$ de 24 de maio de 1974. Diário Oficial da República Federativa do Brasil, Brasília; 1975.

7- Burt BA, Fejerskov O. Water fluoridation. In: O Fejeskov, J Ekstrand, BA Burt. Fluoride in dentistry. Copenhagen: Munksgaard; 1996. p. 275-90.

8- Burt BA, Keels MA, Heller KE. The effects of a break in water fluoridation on the development of dental caries and fluorosis. J Dent Res. 2000;79(2):761-9.

9- Buzalaf MAR, Granjeiro JM, Damante CA, Ornelas F. Fluctuations in public water fluorited level in Bauru, Brazil. J Public Health Dent. 2002;62(3):173-6.

10- Centers for Disease Control and Prevention. Achievements in public health, 1900-1999: fluoridation of drinking water to prevent dental caries. Morb Mort Wkly Rep. 1999;48(41):933-40.

11- Chan JT, Montgomery EH, Wyborny LE, Starcke EN, Thornby JI. Fluctuations in tap water fluoride levels: a potential problem for practitioners. Texas Dent J. 1993;110(2):17-9.

12- Bauru. Secretária Municipal de Saúde. $4^{\mathrm{a}}$ Conferência Municipal de Saúde de Bauru, jun. 2003.

13- De Preto PW, Dias OML, Lopes ES, Bastos JRM. Redução de cárie dentária em escolares de Bauru, após oito anos de fluoretação de água de abastecimento público. Estomatol Cult. 1985;15(3):20-5.

14- Duperon DF, Jedrychowski JR, Kong J. Fluoride content of Los Angeles country water. CDA J. 1995;23(2):45-8.

15- Ferreira HCG, Gomes AMM, Silva KRCS, Rodrigues CRMD, Gomes AA. Avaliação do teor de flúor na água de abastecimento público do município de Vitória-ES. Rev Assoc Paul Cir Dent. 1999;53(6):455-

TABLE 2- Classification of water samples according to fluoride concentration, collected in October 2002 and March $2003 \mathrm{n}$ (\%) in Bauru, SP, Brazil

\begin{tabular}{|c|c|c|c|c|}
\hline \multirow[t]{2}{*}{ Fluoride concentration } & $n(\%)$ & n (\%) & $\%$ total & Classification* \\
\hline & Oct & \multicolumn{3}{|l|}{ Mar } \\
\hline 이 - $0.55 \mathrm{mg} / \mathrm{L}$ & $85(70.8)$ & $11(10)$ & 40 & Unacceptable \\
\hline $0.55 \mid-0.65 \mathrm{mg} / \mathrm{L}$ & $19(15.8)$ & $45(38)$ & 27 & Under fluoridated ${ }^{\star *}$ \\
\hline $0.65 \mid-0.75 \mathrm{mg} / \mathrm{L}$ & $8(6.7)$ & $43(36)$ & 21 & Optimal** \\
\hline $0.75 \mid-0.85 \mathrm{mg} / \mathrm{L}$ & $2(1.7)$ & $18(15)$ & 8 & Over fluoridated ${ }^{\star \star}$ \\
\hline $0.85 \mid-1.15 \mathrm{mg} / \mathrm{L}$ & $2(1.7)$ & $1(1)$ & 1 & Inadequate \\
\hline $1.15 \mid$ - or more mg/L & $4(3.3)$ & - & 3 & Unacceptable \\
\hline
\end{tabular}

* Ramires, $2004^{26}$, modified from Narvai, $2002^{24}$.

** acceptable fluoride concentration. 
16- Horowitz HS. The future of the water fluoridation and other systemic fluorides. J Dent Res. 1990;69(Sp. issue):760-4.

17- Horowitz HS.The effectiveness of community water fluoridation in the Unidet States. J Public Health Dent. 1996;56(Sp. issue)5:2538.

18- Horowitz HS. The 2001 CDC recommendations for using fluoride to prevent and control dental caries in the United States. J Public Health Dent. 2003;63(1):3-10.

19- Marthaller TM. Water fluoridation results in Basel since 1962 health and political implications. J Public Health Dent. 1996;56(Sp. issue) 5:265-70.

20- Modesto A, Tanaka FHR, Freitas DF, Cury JA. Avaliação da concentração de fluoreto na água de abastecimento público do Rio de Janeiro. Rev Bras Odontol. 1999;56(5):217-21.

21- Murray JJ. O uso correto de fluoretos na saúde pública. São Paulo: Editora Santos; 1992

22- Narvai PC. Cárie dentária e flúor: uma relação do século XX Ciênc Saúde Coletiva. 2000;5(2):381-92.

23- Narvai PC. Vigilância Sanitária da fluoretação das águas de abastecimento público no município de São Paulo, Brasil, no período de 1990-1999. São Paulo; 2001. [Dissertação (Livre-Docente) Faculdade de Saúde Pública, Universidade de São Paulo]

24- Narvai PC. Vigilância Sanitária e Saúde Bucal. Texto de apoio ao desenvolvimento de atividades do Curso de Especialização em Vigilância Sanitária da Faculdade de Saúde Pública da Universidade de São Paulo. Modificado em dezembro de 2002. 11p.

25- Oliveira CMB, Paixão HH, Ferreira EF, Prado JBR. Avaliação da fluoretação da água de abastecimento público de Belo Horizonte, MG, após 18 anos. Rev ABO Nac.1998;6(3):153-8.

26- Ramires I. Avaliação da concentração de flúor na água de abastecimento público, antes e depois dos procedimentos de fluoretação. Bauru; 2004. [Dissertação (Mestrado) - Faculdade de Odontologia de Bauru. Universidade de São Paulo].

27- Tavares PG, Bastos JRM. Concentração de flúor na água: cárie, fluorose e teor de flúor urinário em escolares de Bauru-SP. Rev Assoc Paul Cir Dent. 1999;53(5):407-15.

28- Viegas AR, Viegas I, Castellanos RA, Rosa AGF. Fluoretação da água de abastecimento público. Rev Assoc Paul Cir Dent. 1987;41(4):202-4.

29- Viegas AR. Fluoretação da água de abastecimento público. Rev Bras Med. 1989;46(6):209-16.

30- Vertuan V. Redução de cáries com água fluoretada. Rev Gauch Odontol. 1986;34(6):469-71. 